Antoinette Pretorius

Antoinette Pretorius is affiliated to the Department of English Studies, University of South Africa. Her research focuses on older age in transitional and post-transition literature in South Africa. Email: pretoae@unisa.ac.za

\section{Bodily disintegration and successful ageing in Body Bereft by Antjie Krog}

\title{
Bodily disintegration and successful ageing in Body Bereft by Antiie Krog
}

Antiie Krog's Body Bereft (2006) details both the bodily changes brought about by older age and the ways in which these changes fracture a person's previously-stable sense of self. This article reads Krog's depiction of the ageing body in a small selection of poems from this collection in relation to the unavoidable reality of bodily decay and what is referred to in gerontological theory as 'successful ageing'. This tension dominates large parts of the gerontological field, and can be seen in Krog's ambivalent representation of older age in Body Bereft. Through close readings of a number of poems, I will investigate the ways in which Krog problematises the relationship between the lived experience of older age with its concomitant sense of deterioration, and the societal impetus to age well and accept ageing with magnanimity. I will demonstrate that this collection foregrounds the poet's refusal to accept pre-existing discourses that delimit ageing as something either to bemoan or celebrate. I will conclude that this refusal finds particular expression in her poems "dommelfei / crone in the woods" and "how do you say this". Keywords: Antiie Krog; Body Bereft, gerontology; successful ageing, bodily deterioration

\section{Introduction: Mapping the contours of older age}

The construction of old age takes place in and is mediated by very specific sociocultural contexts. Rather than being a predetermined, essentialised category, it exists as a complex conflation of the physical, the social and the political. While ageing is an unfamiliar and unexplored experience that each individual has to undergo in his or her lifetime, there are as many ways of growing older as there are older people. To speak of older age means to speak of an immensely disparate variety of individuals, as this "stage of life $[\ldots]$ encompasses a greater variety than any other" and includes "people aged from their fifties to past one hundred; those possessing the greatest wealth and power, and those the least; those at a peak of physical fitness and the most frail" (Thane 193).

Chris Gilleard and Paul Higgs (3) have defined ageing as "a 'cultural field" realized through the activities and discourse of particular social actors within whose lives it acquires concrete form". As Julia Twigg (60) notes, "The aging body is thus not natural, is not prediscursive, but fashioned within and by culture", where "the body becomes a project to be worked upon, fashioned and controlled, a site of self-identity and reflexivity". This performance of old age is mediated by divergent discourses; the 
most pervasive one speaks of ageing in terms of loss, where "[n]arratives of decline have replaced all other forms of meaning and interpretation of the body in later years, so that other more humanistic or plural readings become impossible" (Twigg 54). In reaction to the ubiquity of this discourse, Rowe and Kahn (1998) advocate the 'successful ageing' paradigm. Stephen Katz and Toni Calasanti (28) explain that this approach identifies "[s]uccessful agers" as "satisfied, active, independent [and] self-sufficient". This, according to Rowe and Kahn (38) could be achieved by "(a) forestalling disease and disability, (b) maintaining physical and mental function, and (c) social engagement". Katz and Calasanti (26), however, criticize this perspective because within this framework "individual choice is reduced to decontextualised healthrelevant choices, such as smoking, diet, or exercise" (29). Furthermore, it implies that "populations are homogenized as either successful or unsuccessful agers" which means that "the diversity of the aging experience is flattened, especially the consequences of social inequalities as they intersect with age relations" (29).

This article aims to examine the ways in which selected poems from Antjie Krog's Body Bereft illustrate the tension between the "successful ageing paradigm" and the "narratives of decline" found in gerontological theories on ageing. My close readings of these poems will elucidate Krog's representation of embodied ageing as fluid and multivalent. Several critics have investigated the concept of ageing in Body Bereft as well as in Krog's oeuvre as a whole. Marthinus Beukes discusses the ways in which the ageing body may be related to poetic form and technique in Verweerskrif. He argues: "[D]it [is] duidelik dat die tema van verbrokkeling dominant is en [dat] die spreker se ouerwordende lyf aan drastiese agteruitgang onderworpe is" (14). Similarly, Adéle $\mathrm{Nel}$ analyses how selected poems from the collection may be read in relation to paratextual elements such as the cover photograph. Both these authors, however, read the ageing body only in relation to narratives of decline, despite their explorations of the ways in which Krog transgresses these discourses. In contrast, in "I have a body, therefore I am': Grotesque, monstrous and abject bodies in Antjie Krog's poetry", Louise Viljoen argues that while "themes of ageing, bodily decay and approaching death (116) dominate the poems in Body Bereft, "there are also attempts to accept [the ageing body] and to be at home in [it]" (123). Viljoen's reading of Krog's representation of the ageing body is most in line with mine: like Viljoen, I aim to investigate the ways in which Krog presents older age as fluid. However, my reading of the poems will be related to gerontological theory that addresses the concerns depicted by Krog.

As Gilleard and Higgs (i) explain, while ageing can be viewed as "a process or processes of biological change occurring after reproductive maturity has been attained $[\ldots]$ it is not clear how determinate these 'ageing processes' are". Furthermore, this "assume[s] the existence of a socialized lifecourse in which a regular distinction is made between adult and later adult life" (Gilleard \& Higgs i). However, these distinctions are in fact fluid, "varying over time and between societies" (Gilleard \& 
Higgs i). As will be elaborated on below, Krog gives voice to this fluidity in Body Bereft (2006), through her emphasis on ageing as a process of becoming, rather than a preexisting condition. She writes of both the difficulty involved in attempting "to eke out/ the vocabulary of old age" ("how do you" 39, my emphasis), and of menopause, in poems such as 'sonnet of the hot flushes" (17).This indicates that the menopausal body and the ageing body exist on a continuum that does not allow for easy delineations, highlighting the fluid nature of the body presented in Body Bereft. This ageing body is often defined by discourses of disintegration and loss. In "how do you say this" (28), the speaking subject articulates this idea when she comments that she does not "know how to write your ageing body / without using words like 'loss' or 'fatal'" (4-5). In order to demonstrate Krog's engagement with this discourse, I investigate "when tight is loose" (23) in relation to the "[n]arratives of decline" discussed by Twigg (54).

However, this discourse of lack is not the only marker of identity ascribed to the older body by Krog. As my analysis below will demonstrate, in other poems Krog presents defiant and resilient older bodies that refuse to be associated with only decline. I will read "manifesta of a grandma" (30) in relation to its engagement with the "successful ageing" paradigm advanced by Rowan and Kahn. I will next demonstrate that through focusing on the multi-layered role played by the body in the experience of ageing, Krog offers alternative modes of representation for bodily identity in older age, and refuses to submit to discourses that delimit the potential meaning of identity in later life. As such, I will analyse "how do you say this" (28) and "dommeflei/ crone in the woods" (68) as examples of poems that escape these narrow delimitations. I posit that in these poems Krog presents alternate visions of ageing that refuse to be pinned down by conventional understandings.

\section{Disintegrating older bodies}

In "when tight is loose" Krog presents us with an ageing body defined by its disintegration (23). This wilfully disintegrating body is described as not "want [ing]/ to be firmly tied and trim" (my emphasis), emphasising the ways in which the speaking subject is no longer in control of her corporeal identity. The poem reinforces this idea of a body in revolt through dissecting the wholly coherent body associated with youth into the fragmented components associated with ageing corporeality. The speaking subject's left eye "bubble[s]" with "its own/eccentric jumpiness", her "upper lip" plays the "accordion", her "upper arm" becomes a flapping "new suede purse" and her "stomach lies like a dish in her lap". Each body part is described as an isolated entity with its own intentions over which the speaker has no control. Not only are "her thumbs [...] crumbling away" but they also "refuse / to open bottles, taps or masturbate". The placement of the word "refuse" at the end of the line and stanza 
emphasises how ageing has signified a transfer of power in the split between self and body, and alludes to the deterioration conventionally associated with ageing.

This collapse is further illustrated in the stanzas that follow. The use of the word "dare" in her "toe-/ nails" that "dare" to "grow so riotous" and the description of "the colon" that almost wilfully "crashes / through its own arse" amplify the ways in her body is now defined by lack and loss. Significantly, the "arse" is described as belonging to the "colon", and not to the speaker, furthering the sense of displacement the speaker feels from her body. This sense of disjuncture between subject and body can also be seen in "God, Death, Love" (21), in which the speaking subject's body is given autonomy as it "no longer / wants to intensify with exhilarating detonations" (my emphasis).

The body's revolt against the speaking subject shifts into the speaking subject's revolt or revulsion at the ways in which her body is changing: her knees are "shrinking like forgotten/prunes" and her skin "is loose from/her flesh like a shuddered boiledmilk/skin". According to Jay Prosser (65), skin serves the function of "individualizing our psychic functioning" and "making us who we are". It "holds each of us together, quite literally, contains us, protects us, keeps us discrete" (Prosser 65). What happens when "tight" becomes "loose" is that the discreteness of the individual begins to be compromised. The body described by Krog in this poem is fragmented into disparate elements that lack coherent meaning. This culminates in the simile that compares the speaking subject's "skin" to a "shuddered boiled-milk / skin", conveying the utter sense of alienation invoked by her experience of ageing. In her discussion of Krog's portrayal of abject bodily identity, Viljoen concludes that while the simile conveys Krog's feeling that the speaking subject's "ageing and menopausal body is indeed an affront to the existing social order", it is also an attempt to "confront society's negation of the menopausal woman by making this body visible in all its abject specificity" (120). While this does convey a sense of empowerment, bodily decline remains the overriding characteristic of Krog's representation of the ageing female body in this instance.

While most of the poem details the speaking subject's embodied experience of ageing, the final three stanzas explore the far-reaching effects of this corporeal disintegration in relation to the rest of the subject's lived reality. Her diminishing daring or "impulse" derives from her "blood", her faltering memory relates to "the dying nerve ends at the outer / edges of the skin" and the inability "to delight/ in bright colours" is the fault of the failing "retina". In each case, the division between herself, her perceptions and her corporeal reality results in a dissolution of her previously established identity. Furthermore, this description illustrates that it is impossible to separate the biological reality of ageing from the cultural construction of older age. This highlights the deterioration and collapse of the older body, and thus illustrates the ways in which ageing is associated with the "[n]arratives of decline" mentioned by Twigg (54). 


\section{Socially-constructed older bodies}

While "when tight is loose" foregrounds the body as the locus of representation, "manifesta of a grandma" is concerned with stereotypes in society surrounding old age generally, and grandmothers specifically. In this comic poem, Krog systematically points out and challenges outdated representations of grandmother-hood by parodying the representation of grandmothers in popular media forms such as newspapers and children's picture books. As will be illustrated below, this has the effect of highlighting the societal impetus that demands "successful ageing" as the ideal way of growing older. The poem starts off with a question, presumably asked by a grandchild: "so how does it feel to be/ a grandma?". Significantly, this question and the imagined facetious response involve issues of societal perceptions and representations of grandmothers. Krog in this poem deconstructs how grandmothers are perceived by both their grandchildren and by society as a whole and gives voice to the difficulty involved in finding an accurate and encompassing definition for the roles and characteristics of grandmother-hood. The first part of the imagined response to the child's question ("...very old thank you") may be related to findings reported in a study by Bäckvik et al, in which the researchers investigate how grandparents are represented in children's picture books and how this relates to the realities of grandparent-hood. This study states that "storybooks are one means by which children can learn and develop attitudes towards grandparents and older adults in general" (299). Since "research indicates that children's books often depict grandparents as very aged", the representations of grandparents in storybooks can be said to shape and simultaneously reflect children's perceptions of their grandparents. More importantly, these depictions very often show grandparents to be homogeneously aged. The facetiousness of Krog's imagined response to the child's question seems to undermine this stereotype. However, in this poem, the speaking subject very pointedly later refers to her "early breeding ability", indicating that she does not fit into the imagined community of "very old" grandparents who populate storybooks and contribute to children's perceptions of their grandparents. Thus, her inability to define grandmother-hood and her resultantly conflating it ironically with being "very old" undermine the idea that to be a grandmother should only mean to be "very old". Furthermore, the second part of the imagined response, ("I don't/ get cock past my lips anymore"), controversially introduces the idea of sexuality to the definition of being a grandmother, and consequently poses the question of whether being a grandmother should mean being desexualised.

Krog goes on to define the characteristics of stereotypical grandparents, using children's books as a starting point. Her analysis of the representation of grandparents in children's books mirrors the findings of the study conducted by Bäckvik et al. Her reference to the "grandma anachronistically [wearing] Dr Scholl's shoes" is supported by their finding that grandparents in children's story books "wear clothes atypical for 
the date of the story" (Bäckvik et al. 300). Furthermore, the study states that "[w]earing glasses is the most common feature attributed to grandparents: nearly half of the grandfathers and over one third of the grandmothers have glasses" (Bäckvik et al. 303). In Krog's poem, both the grandmother and the grandfather wear glasses. According to Bäckvik et al (303), "[g]ender differences appear for accessories such as aprons, sticks, and rocking chairs" and "more grandfathers than grandmothers are portrayed with a stick". In keeping with this, Krog's parodic grandmother is "joyously knitting-spectacled and bunned", while the grandfather "fumbles along with stick, / coat and grey felt hat". Both the grandfather and the grandmother in the children's books described in the poem can be associated with the "aged, fragile, weak, and impaired" (Bäckvik et al. 313) grandparents found in the books analysed by the study, also imply decline, lack and loss. Significantly, despite Krog's reference to the speaking subject's "early breeding ability" which suggests that she considers herself somewhat an anomaly, the study found that the grandparents in children's books are decidedly "older than the average grandparents of young children" (314). This could be attributed to the fact that the authors and illustrators of these books rely on their own memories of their grandparents rather than on the diversity of types of grandparents found in modern society and thus "do not seem to adequately represent the multiple realities of most grandparents of preschool children who are still in the mainstream of life" (Bäckvik et al. 312-3). Krog's statement that the speaking subject's "own children don't even know anyone / with a bun, not to mention [her] culturally mixed-up / grandchildren" points to this discrepancy between the representation of grandparents in literature and the realities of grandparent-hood.

In contrast to the stereotypical images of grandparents found in storybooks, the speaking subject presents the reader with her own first-hand observations of the elderly. This description seems to find resonance with Rowan and Kahn's idea of the successful ageing paradigm. Instead of the "aged, fragile, weak, and impaired" (Bäckvik et al. 313) grand parents found in children's books, these older adults are portrayed as being capable and active. This difference comes across in both Krog's description of their appearance and of their activity. Firstly, instead of having hairstyles stereotypically associated with older age, the women have "short-clipped hair" and the man has a "ponytail", and instead of wearing outdated forms of footwear, they are wearing much more practical and modern "running shoes". The "gent" does not use the parodic wooden walking stick; instead he makes use of an "aluminium strut". Furthermore, he is described as "[n]imbly [...] hop[ping] from the passenger seat" instead of "fumbl[ing] along with a stick" with a befuddled "surprised expression on his face". Secondly, instead of being depicted as busy "joyously knitting", these older adults are on a shopping expedition. This implies that they possess a self-sufficiency and capability that their literary counterparts lack, and are thus representative of Rowe and Kahn's idea of 'successful ageing'. 
The conclusion of the poem returns to the question that was posed at its beginning. While the initial question might appear innocuous enough, the content of the poem is evidence to the contrary and proves that defining grandmother-hood is a complex and problematic endeavour. As has been discussed above, this is because perceptions about being a grandmother are intrinsically connected to the abounding negative, outdated and stereotypical representations of grandmothers in society, in literature and in the media. As a result, the speaking subject's response ("Grandpa and I here on the stoep/ we take it lying down") implies that being a grandparent revolves around the tension between the almost inevitable onslaught of these representations and the subject's need to retain a positive and unique sense of identity while being a grandmother. This can be seen when contrasting the almost resigned acceptance in "we take it lying down" with the poem's attempts not simply to accept these negative stereotypes. In light of the remainder of the poem, the subject's sense of resignation itself becomes a mocking reaction to the social pressure that demands acquiescence in older age.

This may be related to the discourse that speaks of older age in terms of bodily disintegration, and the simultaneous impetus that demands 'successful ageing'. Krog highlights the fluidity of the construction of identity in older age through foregrounding these divergent identities in this poem and throughout the collection.

\begin{abstract}
Alternative older bodies
In "how do you say this", Krog (28) most cogently expresses the tension between the narratives of decline that characterise the lived experience of older age, and the societal impetus that demands successful ageing. Despite claiming not to know how to write the ageing body, Krog attempts to do so in this poem that describes a sexual experience between two older bodies. She achieves this through liberating the ageing body from being a self-enclosed marker of identity characterised only by lack and loss. Instead of giving in to the reductiveness involved in categorising the components of the ageing body in an unaccommodating language that inevitably has to render a "wrinkle [...] banal", she instead gives a subjective account of a bodily experience. Through focussing on how an ageing body perceives and interacts with another ageing body, she is able to avoid pinning down the body, and the meaning ascribed to it instead becomes fluid and shifting, as we see the speaking subject attempting to overcome conventional ideas of the limited sexuality accorded to an ageing individual. Stephen Katz and Barbara Marshall (4) write that historically "sexual decline was assumed to be an inevitable and universal consequence of growing older; thus, aging individuals were expected to adjust to it gracefully and to appreciate the special moral benefits of post-sexual maturity". While Krog does in this poem describe the maturity associated with ageing, this maturity is decidedly sexual in nature and centres on the changing dynamics of the sexual experience brought about by older age.
\end{abstract}


Instead of focussing on what has been lost in the process of ageing, this poem details what has been gained. However, the difficulty involved in avoiding conventional descriptions of the ageing body can be seen throughout the poem. As it progresses, her rendering of the experience into a new language of the ageing body becomes clearer. For example, while discussing the difficulty of writing the ageing body at the beginning of the poem, she describes a beard that is "too close for language" and "too grey with grit". However, in the next section of the poem, she attempts to find new words with which to describe the greyness of her partner: the beard becomes "grey hair [that] crackles like lightning", indicating a sense of power that the previous description lacks. However, she lapses into a narrative of decline in the next line when she describes his "face of erosion", alluding to the conventional trope of the erosion of time on the body. The "wrinkle" referred to at the beginning of the poem becomes "the grooves cutting down from [his] ears", and his "scalp surprises [her] with its own texture". Here we begin to see Krog articulate more innovatively the speaking subject's love for a familiar body that has paradoxically become new as the process of ageing allows it to reveal itself to her in unexpected ways. Furthermore, the newness of her partner's body allows her to experience her own body in new ways. Equally importantly, the newness of the experience allows her in turn to transcribe the experience into a language that resists the conventional delimitation of the ageing body into a narrative of decline.

As described by Beukes (8) in his reading of the Afrikaans version of the poem, the speaking subject initially frames her doubts about her ability to represent the ageing body in language with qualifiers such as, "I truly don't know", "I really don't know", and "I simply do not know". In the middle part of the poem, in which she attempts to find a language for the experience, she changes this to "I think / I'm trying to say". Here, the description of her partner's ageing body as well as her reaction to it become sexualised. Instead of describing his beard, his hair, or his wrinkles, she writes that she finds "the thickening of [his] / abdomen attractive" and that "an erection against a slight curve leaves one wet in the mouth". Almost as if abandoning convention and propriety altogether, she continues, "god, / I think I'm trying to say that I can surrender to / your thighs for the very first time because of / their soaking whiteness". She prefers "the soft/ looseness of [his] buttocks to the young hard/aggressive passion" of their youth. As she delves deeper into the sexual dynamics of the experience itself, she abandons the use of qualifiers, and explains that the fact that he "no longer / want[s] to breed children from" her grants her enjoyment of "the luxury of experience", not despite of but because of their maturity. This is the poem's most striking example of Krog's refusal to lapse into the narrative of decline associated with the process of ageing. Ageing is generally seen as undermining female identity, as it marks the end of a woman's reproductive capacity. Here, instead of regarding this as a loss of identity and value, Krog undermines the conventional view and celebrates the sexual satisfaction that has been gained because of older age. 
The poem concludes with an allusion to Dylan Thomas's poem "Do not go gentle into that good night" (1952). In his famous poem, Thomas urges his dying father to fight for the life remaining to him, and not to accept his impending death meekly. Significantly, he does this from a relatively youthful perspective, as he was 37 years old at the publication of the poem. While Krog does not seem to dispute the importance of "rag[ing] against the dying of the light", she emphasises that "at times it seems easier to rage" against this than "to eke out/ the vocabulary of old age". Her allusion makes the point that fighting against death is easier than living with old age and writing from an ageing perspective. She reiterates this sentiment in her poem "God, Death, Love" (21), when she writes that "to jump from the ageing body to Death/has suddenly become a cop-out act". Furthermore, her allusion to the Thomas poem serves to highlight the way in which the ageing body has been muted in literature, in favour of the more classically acceptable metaphor of Death. Significantly, despite her attempts to write the ageing body in "how do you say this", she concludes the poem not on a triumphant note, but rather with an acknowledgement of the difficulty involved in the writing process. This seems to undermine reading the poem only as a celebration of postsexual maturity, as it highlights the constructed nature of old age and emphasises its often-contradictory fluidity.

In "Dommelfei/ crone in the woods" (68), Krog presents an alternative reaction to menopause as well as an alternative representation of grandmother-hood and growing older. Krog cites Mario en die diere ("Mario and the Animals", 1939) by Waldemar Bonsels as her intertextual inspiration for the poem. Originally written in German and later translated into Afrikaans, Mario en die diere details the experiences of a young orphaned boy who runs away into the woods after the death of his mother in order to escape being sent to an orphanage. Here, he meets Dommelfei, the crone in the woods, who takes him in and teaches him about animals and the woods. While it is clear that Mario en die diere only serves as a very loose intertextual reference to the poem, the characterisation of Dommelfei does carry through into Krog's poem, as will be shown below.

The poem starts off by listing the identity markers the subject of the poem can no longer claim as her own. She "no longer reads books", "listens / to music" or "watches television". Significantly, this description rests on how the subject previously identified herself and why this identity is no longer available to her. The over-riding effect of this section is to highlight the ways in which she is cut off from a world she previously inhabited, and seems to suggest that she should be identified by decline, lack and loss. This isolation from the world that she experiences can be seen in Bonsels's text, where Dommelfei takes great care to shun the society outside of the woods. However, the difference between the story and this poem is the modernization evident in the poem, as can be seen through its reference to the "television", marking the shift between it and the source-text. This, in turn, allows this poem to speak to the other 
poems in the collection that also deal with the representation of grandmothers and their identity. While this section is initially characterised by a script of negation, the fact that "no children / can come from her any/more" (alluding to society's conflation of feminine value and fertility), is mediated by her "refus[al] to raise/[the children] of others", which is an active decision defined by neither lack nor loss. Thus, at this point, she begins to describe the identity markers she rejects and refuses to assume, stating that "she has no interest in the inner/power mechanisms of men". Here, Krog depicts older age as an escape from the "demands of gender and behaviour". While the first section of the poem illustrates the ways in which Dommelfei's identity is no longer marked by the social and cultural mores of the world, her ageing is described in this section as not being mediated by identification with the world of men. Interestingly, the fact that "old men render her sad" seems to suggest that she feels a sense of comradeship towards older men that she does not feel towards men who are still embroiled in the machinations of power associated with youth. The poem's singular reference to Red Riding Hood can be seen in this section, when Dommelfei states that "a red-hooded grandchild" is on the way to her. Krog's choice of article in this description seems to resist a direct connection between Dommelfei and the grandchild: it is not "her" grandchild that is being described. This allows for further disassociation from identity markers typically associated with grandmother-hood. Significantly, the original Dommelfei takes Mario in and looks after him not because he is her grandchild, but rather because she chooses to do so. Furthermore, this reference allows Krog to reconceptualise the original Red Riding Hood story so that the female figures now are resilient: the grandmother is no longer bed-ridden and helpless, but canny and powerful, and the grandchild moves securely on "sturdy legs" and is no longer innocent and vulnerable to predation. The reference to "rid[ing] her life out/ like a song" inscribes older age with sweetness and freedom, rather than decline and lack. The "apron" can be read as an apt reference to the burden of womanhood that Dommelfei's older age allows her to ignore. After the asterisk, the negation of the first section gives way to a description of what does define her identity. Here, the negative connotations of witchery associated with crones are broadened and redefined to suggest an affinity with and connection to the powers of nature. This section undermines mechanised ideas of conventionally organised time. Instead of being regulated by imposed conditions of linearity, Dommelfei's habits are shaped according to a more natural allegiance to the rhythms of nature. Instead of undergoing hormone replacement therapy or subjecting herself to a hysterectomy, she makes use of natural ingredients to alleviate her menopausal symptoms. This additionally counters the conflation of crones with witches who cast spells or concoct malevolent potions. The poem concludes on a disturbingly threatening note. This last section starts off positively and self-reflexively addresses the reader in a sinister manner, stating that Dommelfei will "knead your thighs" and "minister your" arms with 
"balms". The focus moves from the reader's physicality to elements associated with language and the reader's cognition, namely their "mind" and their "tongue". This uncanny separation of mind and body is a departure from the "comfort" Dommelfei will provide. Significantly, the poem finishes with what may be a reference to "A Prayer for Old Age" by W. B. Yeats (1956):

God guard me from those thoughts men think

In the mind alone;

He that sings a lasting song

Thinks in a marrow-bone;

From all that makes a wise old man

That can be praised of all;

O what am I that I should not seem

For the song's sake a fool?

I pray-for word is out

And prayer comes round again-

That I may seem, though I die old,

A foolish, passionate man.

In this poem, Yeats expresses his lifelong dissatisfaction with the dualism that separates mind and body in Neoplatonic thought, implying that "intellect by itself leads to barrenness, intellectual sterility [...] but a unity of thought and emotion instead prompts fecundity" (Bornstein 56). This points to Yeats's belief that it is "the self's polarization of experience into the Neoplatonic divisions of pure and impure, bodily and spiritual, inner and outer that inhibits its attainment of completion" (Wilson 33). This is exemplified by his distinction between "think[ing]/in the mind alone" and "think[ing] in a marrow-bone". Thus, to Yeats, the "marrow-bone" becomes a symbol of the ways in which mind and body, and thought and emotion, should be unified rather than polarized. By stating that Dommelfei is able to "unfasten" the reader's "mind" and "preserve" his or her "tongue", Krog locates Dommelfei's source of power in her ability to "think [...] in a marrow-bone". While the reader will also be sent "alone into the cold wind of ageing", he or she will be "searing from the marrowbone". The warm intensity of the word "searing" stands in stark contrast to the "cold wind" Krog associates with "ageing". The "cold wind" could be read in relation to the narratives of decline discussed by Twigg (54), while the "marrow-bone" alludes to the alternative and more positive approach to ageing suggested by both Krog and Yeats. However, the ambiguous connotations suggested by the use of the word "searing" point to the difficulty involved in reconciling the realities of bodily disintegration with the societal impetus that demands 'successful ageing'. It is thus possible to conclude that this poem best represents Krog's refusal to delimit the ageing identity to being defined either by bodily decline or according to the impetus that 
demands a homogenised idea of 'successful ageing'. Krog does not attempt to deny or negate the inevitable reality of ageing. Instead, she points out the existence of alternative reactions to growing older, as well as other ways of representing older age in literature.

\section{Conclusion}

Body Bereft, as a whole, demonstrates the multivalent nature of identity in older age. While presenting the negative bodily changes brought about by age as important aspects in the construction of this identity, Krog does not delimit the older body to being defined only in terms of degeneration, lack or loss. Similarly, while she does suggest that many elderly people are more independent and active than their literary counterparts, her emphasis on the realities of the changing older body implies that she does not ascribe to the societal impetus that demands 'successful ageing' as the standard against which all older people should be judged. Instead, through giving voice to these often-contradictory ways of reading older age, she shows that the meaning ascribed to it should be fluid rather than fixed, and that the ageing identity is above all defined by its multi-layered nature.

\section{Works Cited}

Bäckvik, P., H. Hurme, M. Rusek, C. Sciplino \& P. Smith. “Representations of Grandparents in Children's Books in Britain, Italy, Greece, Finland and Poland". Journal of Intergenerational Relationships. 8.3 (2010): 298-316.

Beukes, M. "Ikonisering van liggaamsverval met spesifieke verwysing na Antjie Krog se bundel Verweerskrif". Stilet. 23.1 (2011): 1-17.

Bonsels, W. Mario en die diere. Trans. A. E. Carinus. Pretoria: Van Schaik, 1939.

Bornstein, G. "W. B. Yeats's Poetry of Aging". Sewanee Review. 120.1 (2012): 46-61.

Gilleard, C. \& P. Higgs. Contexts of Ageing: Class, Cohort and Community. Cambridge, UK: Polity, 2005.

Katz, S. \& T. Calasanti. "Critical Perspectives on Successful Aging: Does It "Appeal More Than It Illuminates?"”. The Gerontologist 55.1 (2015): 26-33.

Krog, A. Body Bereft. Roggebaai: Umuzi, 2006.

Nel, A. "Liggaam, teks en parateks in Antjie Krog se Verweerskrif". Litnet Akademies 5.3 (2008): 51-68.

Prosser, J. Second Skins: The Body Narratives of Transsexuality. New York: Columbia UP, 1998.

Rowe, J. W. \& R. L. Kahn. Successful Aging. New York: Random House, 1998.

Thomas, D. In Country Sleep and Other Poem. London: New Directions, 1952.

Twigg, J. "The body, gender and age: Feminist insights in social gerontology". Journal of Aging Studies 18 (2004): 59-73.

Viljoen, L. "'I have a body, therefore I am": Grotesque, monstrous and abject bodies in Antjie Krog's poetry". Judith Lütge Coullie \& Andries Visagie, Andries. (eds.) Antjie Krog: An Ethics of Body and Otherness. South Africa: U of KwaZulu-Natal P, 2014.

Wilson, B. M. "'From Mirror after Mirror": Yeats and Eastern Thought". Comparative Literature 34.1 (1982): 28-46.

Yeats, W. B. Collected Poems of W. B. Yeats. New York: Macmillan, 1956. 